\title{
20 YEARS IN THE SERVICE OF THE NATIONAL MACHINE-TOOL INDUSTRY
}

\section{Georgiy SAMODUROV*}

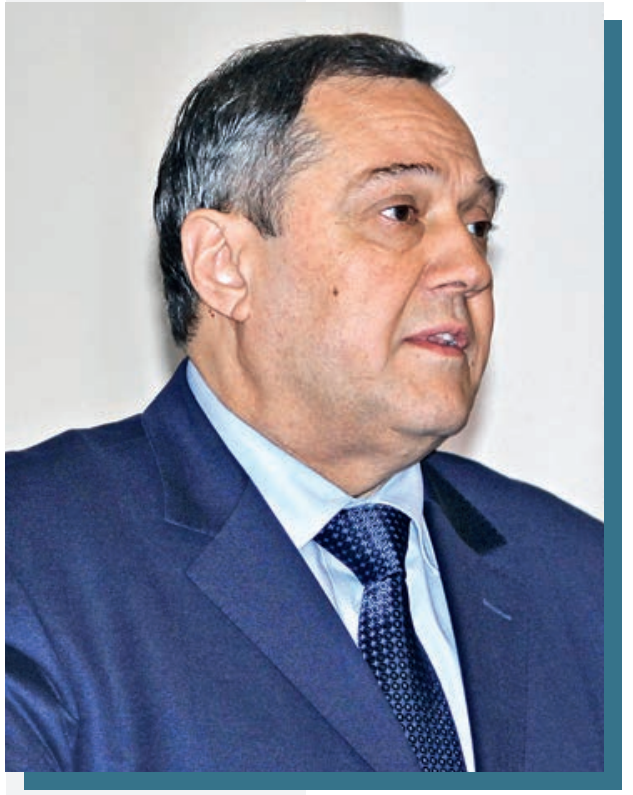

the metal-working equipment production volume exceeded 80,000 pieces including 22,000 machine-tools and CNC presses, and 5,000 machining centres and flexible industrial processing lines. It necessitated, in its turn, to develop cooperation and attract a huge number of purchased parts: joint stock company "Stankoinstrument" as a system integrator though, later, it was liquidated as a result of the USSR disintegration.

In 1992 in the Russian Federation a public joint stock company (PJSC) "Kompaniya "Rosstankoinstrument" was registered. However, the developing economic processes in the country, namely, converting enterprises into joint stock companies in the absence of the established legal framework did not allow to the develop the PJSC "Kompaniya "Rosstankoinstrument".

On March 5, 1999 Association "Stankoinstrument" was established by the founders: PJSC "Kompaniya "Rosstankoinstrument", PJSC "Krasniy Proletariy" and PJSC "VNIIINSTRUMENT". On the same date the founders meeting approved of the Articles of Association. Since that time the 5 March is traditionally considered to be the birthday of the Association.

The fathers of our Association were: N.A. Panichev (President, PJSC "KomCNC, transducers, electrical equipment, hydraulic equipment, etc.

It is apparent that it was unrealistic to achieve all that without coordination and scientific support of the industry enterprises. Therefore, in the very beginning of the so-called "Perestroika" and subsequent close up of the industry ministry the managers of enterprises and organizations initiated establishment of a state-owned

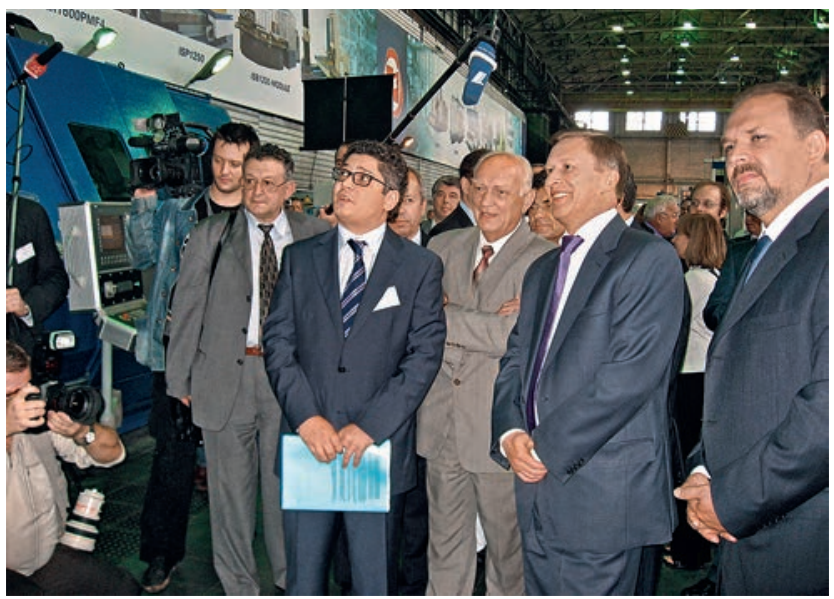

* President, "Stankoinstrument" Association

In the middle - Nikolai A. Panichev 


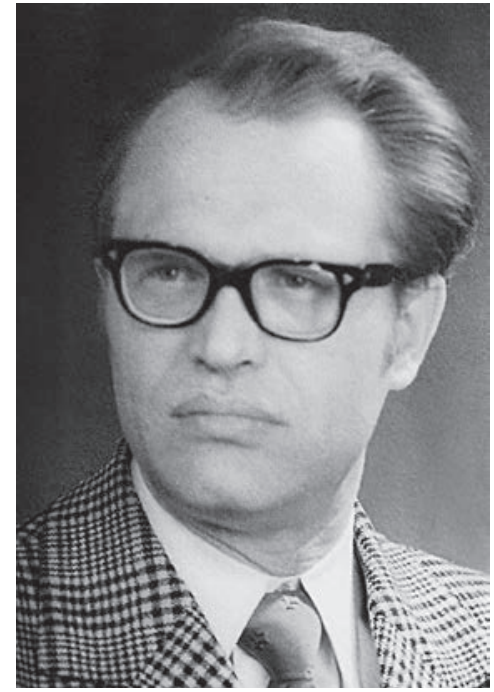

V.M. Lakhtyuhov paniya "Rosstankoinstrument”, Minister of Machine-tool and Tool Industry of the USSR in 19861991), V.N. Efimov (Manager of the New Technologies, External Relations and Exhibition Activity Department, PJSC "Kompaniya "Rosstankoinstrument”), V.M. Lakhtyuhov and A.A. Naumov (Deputy Managers of the New Technologies, External Relations and Exhibition Activity Department, PJSC "Kompaniya "Rosstankoinstrument").

V.N. Efimov became the first Director General of the Association, then he was succeeded by S.V. Vasilyev. In 2002 N.A. Panichev was elected President of the Association and in 2004 G.V. Samodurov superseded him as the President and remains in this position until present time.

In 2002 the Board of Directors was set up and commenced to consider the most acute problems of the industry and issue recommendations how to solve them. Since 2002 the Board of Directors was presided by V.P. Isanin who devolved his authority to N.A. Panichev in 2004. In 2012 G.V. Borovskyi was elected Chairman of the Board and N.P. Panichev was appointed the Honorary Chairman of the Board.

The first members of the Association were such enterprises as "Tiazhpresmash", "Tiazhmekhpress", "Siblitmash", "SASTA", "Donpressmash”, "Ivanovsky

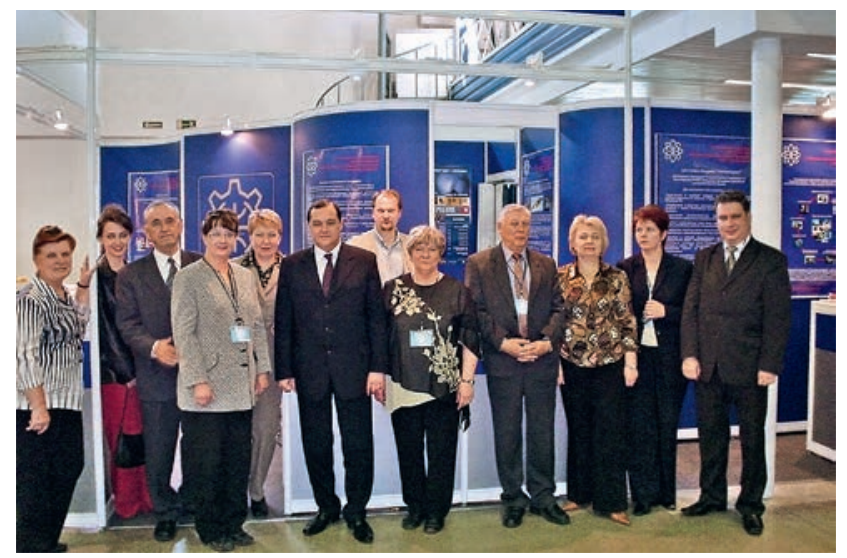

Collective body of the Association of MachineTool and Tools Producers "Stankoinstrument"
ZTS", "SAVMA", "MIZ", "Stankozavod Ordzhonikidze" and others - altogether about 20 enterprises.

Nowadays the Association of the machine-tools and tools manufacturers unites more than 160 enterprises and organizations, engineering companies and research institutions of the machine-tool and tools industry that make products and provide services in the sphere of innovative material processing technologies, development of high-tech complexes of metal-cutting, press-forging and foundry equipment, tools, machining attachments and purchased parts, instrumentation industrial automation systems and software.

"Stankoinstrument" Association aspires to consolidate efforts and enhance potential of the machinetool industry enterprises. A permanent cooperation with the Council of Federation of the Russian Federation concerning development of the machine-tool industry is ongoing via the committees and commissions. "Stankoinstrument" Association maintains a close cooperation with the Ministry of Industry and Trade and Ministry of Economic Development in the

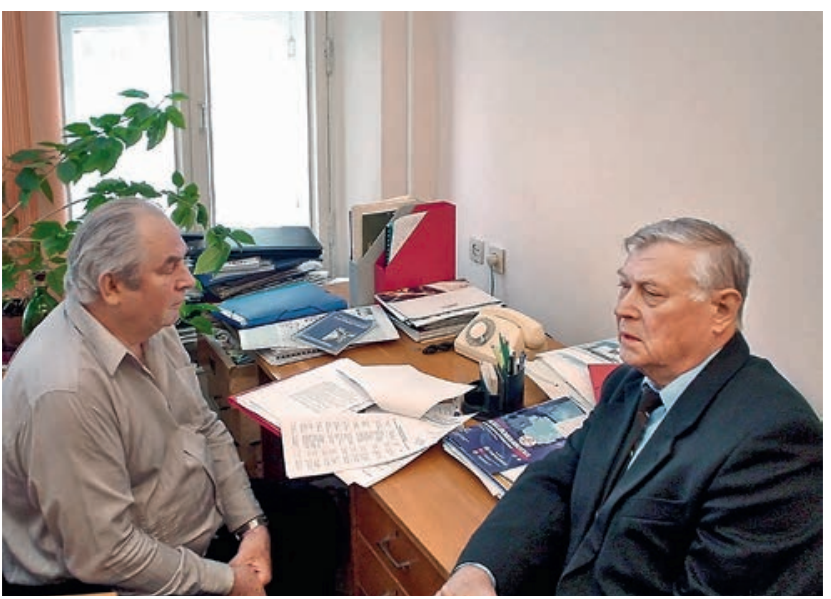

V.N. Efimov and A.A. Naumov

development and implementation of the state support of the branch including Resolutions of the Government No. 9 of 14 January, 2017 and No. 719 of 17 July, 2015 as well as Orders of the Ministry of Industry and Trade of the Russian Federation No. 889 of 27 March, 2017, No. 640 of 8 April, 2014 and No. 4358 of 12 December, 2017.

The Association maintains connections with such public organizations as: All-Russia Public Organization "Russian Engineering Union” (LLC "Soyuzmash of Russia"), Chamber of Commerce and Industry of the Russian Federation (RF CCI), Russian Union of Industrialists and Entrepreneurs (RUIE), Russian Union of Producers (RUP), Civic Chamber of the Russian Federation and Moscow Chamber of Commerce and Industry. Jointly with the Chamber of Commerce 
and Industry of the RF, Russian Engineering Union, Russian Union of Industrialists and Entrepreneurs, the Association is engaged in discussion and refinement of the federal law drafts, concepts, development strategies of the national machine-building complexes and appraisal of their regulating influence.

"Stankoinstrument" Association is a member of the Chamber of Commerce and Industry of Russia. The Association President participates in the work of the RF CCI Council and the Council for industrial development and competitiveness of the Russian economy at the RF CCI.

The President of "Stankoinstrument" Association is included in the Board of the Russian Engineering Union and presides in the Committee at the Central Council Bureau for machine-tool building and tool industry of the Russian Engineering Union.

The Association is a member of the Russian Union of Industrialists and Entrepreneurs, Moscow Chamber of Commerce and Industry and the Russian Union of Producers and collaborates with them in the pressing problems of the national economy development.

Joint activity of the Association with public organizations makes it possible to shape opinions of the federal authorities representing the executive branch, specialists and experts on a necessity to support and develop the national machine-tool and tool industry. Based on the results of participation in round tables, conferences and sessions of the committees and commission the Association presents its proposals and comments to the Presidential Administration of the Russian Federation, National Duma, Ministry of Industry and Trade, Ministry of Economic Development and federal authorities of he executive branch.

The Association cooperates with the administrations of the Russian regions on the basis of the Agreements on social, economic and technical cooperation aimed at social and economic partnership and preservation and development of the production and scientific research potential of the machine-building organizations and coordination of the joint efforts to solve the problems that the machine-building organizations face.

Close collaboration exists with the Association enterprises that produce machining centres, CNC machine-tools, press-forging and foundry equipment and all kinds of tools; monitoring of these enterprises is accomplished on a quarterly basis and it facilitates, to a great extent, working out solutions and making decisions on various support measures.

The Association also interacts with technical universities within the frame of the concluded agreements on the development and approval of the joint work plans. Such agreements have been concluded with 16 higher institutions such as MSTU "STANKIN", Donskoy STU, Bauman MSTU, Peter the Great St.
Petersburg PU, MSTU “MAI”, Novosibirsk STU, Moscow Polytechnic University and others.

Enterprises of the industry conclude contracts for research developments and training of personnel with more than 35 technical universities.

Jointly with the technical universities, the Association applied to the RF Ministry of Education concerning various issues of training specialists and assisted technical universities in diverse aspects of new training forms, new status, etc.

Exhibit displays "Science, specialized education, production" were presented at exhibitions "Metalworking" and "Technoforum".

Within the frame of the exhibitions the Association participated in the conferences "Main trends and methods to train specialists in metal-working". Apart of that, researchers of the higher training institutions made their presentations in the traditional conferences held by the Association.

The Association collaborates with 12 Russian industrial associations and unions of the machinebuilding industries. The concluded agreements provide for performance of the coordinated works along the following lines of activity:

$\rightarrow$ creation of conditions for the development and accomplishment of the retrofitting programs for the enterprises and organizations that are members to the PJSC on the basis of the consolidation of their research, technical ad engineering potential;

$\rightarrow$ holding exhibitions, seminars, "round tables" and workshops devoted to the production activities, advanced technologies, novel kinds of equipment and tools, etc.;

$\rightarrow$ participation in the development and implementation of the regional programs;

$\rightarrow$ participation in the activities of the federal organizations:

$\rightarrow$ structuring conditions and information media that facilitate fund-raising, using banks and other sources, to develop and accomplish the retrofitting programs for enterprises and organizations.

"Stankoinstrument" Association signed Memoranda of cooperation and teamwork with the leading machine-tool building associations of Germany, Switzerland, Czech Republic, Italy, Republic of Korea, Taiwan, Great Britain and others. The key points of the Memoranda are:

$\rightarrow$ exchange of the statistics concerning development of the national machine-tool production;

$\rightarrow$ support of the associations' members on the domestic and foreign markets;

$\rightarrow$ provision of possibilities to participate in the national exhibition projects, including displays of joint work exhibits; 
$\rightarrow$ development of the long-term cooperation between the national machine-tool producers and the members of the national machine-tool building associations.

Machine-tool building is a technological fundcreating branch which is fundamental for upgrading the whole industry. Advanced solutions for upgrading the Russian machine-building complex are presented at the international specialized exhibition "Equipment, instruments and tools for metal-working industry "Metalworking".

It is exactly the exhibition where the branch specialists are able to get information about current world trends in the creation of new equipment and metal processing technologies.

This largest in Russian and C.I.S. innovation project in the machine-tool building is accomplished by the CEC "Expocentre" in partnership with the Association and with the support of the Federation Council of the Federal Assembly of the Russian Federation, Ministry of Industry and Trade, and Engineering Union of Russia. The industry forum is traditionally held under the aegis of the Chamber of Commerce and Industry of the RF and the Moscow Government.

"Metalworking" biannual exhibition (in evennumbered years) was held since 1984. Under new economic conditions it preserved its reputation with authorities and professional circles and is a business card of the current machine-tool building industry of the country. As of 2010 "Metalworking" exhibi- tion is successfully held in the CEC "Expocentre" every year.

International recognition of the industry forum was confirmed by the badges of excellence of the Global Association of the Exhibition Industry (UFI) and Russian Union of Exhibitions and Fairs (RUEF). The exhibition possesses a deserved recognition among world producers of metal-working equipment. No doubt that the exhibition gives a new momentum to the machine-building complex development, particularly to the innovative machine-tool building in Russia with the active use of the international cooperation mechanisms, attraction of investments and setting up joint production facilities.

According to the rating of the RF CCI and RUFF, "Metalworking" was acknowledged to be the best Russian exhibition in "Machine-building, metalworking, machine-tools and industrial equipment" in all categories: "International Recognition", "Professional Interest", "Market Coverage" and "Exhibition Space". All exhibition figures were confirmed by the official exhibition audit.

While promoting the most advanced processing solutions in the national machine-building, "Metalworking" Exhibition facilitates formation of the innovation-driven economy in Russia and accelerates conversion of the challenging high-end developments into a commercial product and implementation of such product in all industries.

Twenty years of "Stankoinstrument" Association activity have demonstrated in reality its reputation and ability to skilfully and effectively perform its main function for protection of interests of its members and be a centre in cooperation of the enterprises on the industry scale.

The Managing Directorate of the A s s o c i a t i o $\mathrm{n}$ expresses its appreciation and gratitude to the enterprises and organizations that are members to the Association for the cooperation in our common deed development of the national machinetool building. 